\title{
CARBON DYNAMIC SHIFTS WITH LAND USE CHANGE IN MARGALLAH HILLS NATIONAL PARK, ISLAMABAD (PAKISTAN) FROM 1990 TO 2017
}

\author{
Mannan, A. ${ }^{1}-$ Feng, Z. ${ }^{1,2^{*}}-$ AhMAD, A. ${ }^{3,4}-$ LiU, J. ${ }^{1,2}-$ SAEED, S. $^{2}-$ MuKete, ${ }^{2}$ \\ ${ }^{1}$ Beijing Key Laboratory of Precision Forestry, Beijing Forestry University, 100083 Beijing, \\ China \\ ${ }^{2}$ Key Laboratory for Silviculture and Conservation of Ministry of Education, Beijing Forestry \\ University, 100083 Beijing, China \\ ${ }^{3}$ Department of Forest Sciences, Beijing Forestry University, 100083 Beijing, China \\ ${ }^{4}$ Shaheed Benazir Bhutto University, Sheringal Dir Upper, KPK, Pakistan \\ *Corresponding author \\ e-mail: fengzhongke@126.com; phonelfax: +86-138-1030-5579; address: No. 35, Tsinghua \\ East Road, Haidian District, Beijing, P. R. China
}

(Received $10^{\text {th }}$ Feb 2018; accepted $9^{\text {th }}$ May 2018)

\begin{abstract}
Land use change (LUC) particularly the conversion of forest to other land uses, determines the scale of forest carbon shifts. Here, remotely sensed data Multispectral Satellite Images (MSI) of the study area for the year 1990, 2000, 2010, 2017 and geographic information system (GIS) tools were used to analyze the land use change patterns. For biomass calculation and related forest carbon losses in the Margallah Hills National Park of Pakistan the field inventory data were collected by random forest sampling from 1990 to 2017 . Our results showed that during the period from 1990 to 2017, the area under dense forest decreased by $11.14 \%\left(0.41 \% \mathrm{yr}^{-1}\right)$, while the area under open forests increased by $4.28 \%\left(0.15 \% \mathrm{yr}^{-1}\right)$. Similarly, agricultural land and settlements increased by $53.17 \%\left(1.96 \% \mathrm{yr}^{-1}\right)$ and $67.78 \%\left(2.51 \% \mathrm{yr}^{-1}\right)$ respectively, during the same period. The conversion of forests into other land uses resulted in the reduction of carbon value. In 1990, carbon loss is estimated at $5531.5 \mathrm{MgC} \cdot \mathrm{yr}^{-1}$ $(7.22 \%)$ of the total carbon pool. Overall, land use change released $154 \mathrm{GgC}\left(5.70 \mathrm{GgC} \cdot \mathrm{yr}^{-1}\right)$, highlighting that land use change significantly alters carbon dynamics of the Park. Land use change and related carbon losses indicating the magnitude of anthropogenic disturbances in the Park. The preservation and rehabilitation of degraded forest as well as reforestation of the converted forests are necessary for forest carbon conservation meeting emissions reduction obligations of the Kyoto Protocol.
\end{abstract}

Keywords: remote sensing, forest loss, satellite images, land use change, carbon loss

\section{Introduction}

Land Use Change (LUC) is the modification of the earth's surface due to human activities which result in the disturbance of the Earth's natural ecosystem and environmental processes (Lambin, 1997). The availability of LUC data has had an important role in advancing research and providing long-lasting solutions to environmental and ecological policymakers (Zhao et al., 2004; Ullah et al., 2016; Mukete et al., 2017). For instance, LUC has become the key issue in many disciplines like forestry, agriculture, environmental sciences, geology and hydrology (Weng, 2001). Additionally, LUC has been greatly applied in studies relating to soil degradation, cropland loss, urban expansion, desertification and deforestation within the past three decades. LUC has been known to cause long-term effects on forest 
ecosystem functions such as a net decrease in forest area globally from $31.6 \%$ to $30.6 \%$ since 1990 (FAO, 2015).

The application of MSI in LUC studies has gained precedence in detecting and estimating both spatial and temporal dynamics of forest cover changes. In our study remote sensing data at periodic intervals and Geographic Information System (GIS) provide information for land use change analysis, modeling, and management (Sudhakar Reddy et al., 2008; Kennedy et al., 2009). For instance, using LANDSAT data and digital analysis the detection of land degradation due to waterlogging and soil salinization occurring over a 10-year period in China was enabled(Gao and Liu, 2010). Similarly, Rembold et al. (2000) used LANDSAT TM data between 1972 and 1994 to estimate land cover changes in central Ethiopia. This is because monitoring through satellite images is not only cost-effective and fast but also provides reliable land use and land cover change detection information (Martin and Tracy, 2007). Within the past three decades, various change detection techniques using satellite imagery have been developed including post-classification comparison (PCC), image differentiation, principal component analysis (PCA) and vegetation index differencing (Lu et al., 2004). Among these, many studies have found the post-classification comparison to be the most accurate procedure especially as it represents the nature of changes as they occur. This method is also thought to reduce problems associated with multi-temporal images recorded under different atmospheric and environmental conditions (Yuan et al., 1999).

Forests are the largest sources of global terrestrial carbon sink, while LUC is the key factor which determines the extent of carbon sink over time (Pan et al., 2011). Forests have a key role in carbon sequestration which is distorted by LUC and land management activities (Abatzoglou et al., 2017). From 1985 to 1990 LUC and land management activities released over $156 \mathrm{PgC}$ into the atmosphere, particularly in tropical areas where deforestation was observed to have caused approximately $60 \%$ of these emissions (Houghton, 2003). Since the 1980s, LUC in Forest land and grassland has been responsible for forest carbon sink in North America and Europe (Nabuurs, 2013). LUC associated with deforestation and land degradation emits $\mathrm{CO}_{2}$ and other greenhouse gases and therefore it emerged as a burning issue in the scientific community (Thompson et al., 2011). However, in a recent economic survey, LUC would affect over $36 \%$ of the United States land area. This is attributed to increased urban land and where urban developmental factors such as culture and socio-economic would be major contributors (Radeloff et al., 2012). In addition, there are also chances and risks of forest conversion into new land uses including agriculture and settlements (Searchinger et al., 2008). Furthermore, concerns about climate change have forced many countries to monitor terrestrial carbon. The Inter-Governmental Panel on Climate Change (IPCC) guidelines for national greenhouse gases strictly requires monitoring of carbon pool through the effect of land-use change and wood removal (IPCC, 2006).

LUC and their associated impacts on forest cover have been widely addressed by the United Nations Framework Convention on Climate Change (UNFCCC). The UNFCCC has also developed guidelines for member countries to measure LUC and related activities. Pakistan as a member of the UNFCCC and IPCC has to follow the proposed greenhouse gas emissions and removal related guidelines. Only about $4 \%$ of Pakistan's total land area is under forest which is under threat from deforestation (Cochard and Dar, 2014). 
In Pakistan, most studies focused on sequestered carbon in different forest types such as in subtropical forests (Nizami, 2012) and in forest plantations (Ahmad and Nizami, 2015; Ahmad et al., 2015; Saeed et al., 2016). Similarly, studies were conducted about the carbon stock in Oak Scrub Forest of Sheringal Valley Dir Kohistan (Khan et al., 2015), and the carbon stock in Chichawatni irrigated plantation in Pakistan (Muhammad et al., 2017). Most of these studies evaluated carbon stocks in particular land use types (Ahmad and Nizami, 2015), while others focus on land use change and deforestation patterns (Hassan et al., 2016). However, none of these studies has been carried out on LUC and their related carbon losses in protected areas. In order to determine LUC and carbon induced emissions in a protected area in Pakistan, the present study in Margallah Hills National Park (MHNP) of North West of Islamabad aims to determine LUC and carbon induced emissions in a protected area in Pakistan.

MHNP has subtropical broad-leaved evergreen, subtropical chir pine forests and rich in flora and fauna. It is one of the best-protected areas in Pakistan providing medicinal plants, economic and aesthetic values to surrounding communities and the country. However, in the past three decades, land use change and deforestation have ultimately released considerable amounts of carbon into the atmosphere. This study, therefore, presents a comparative analysis of the temporal LUC and forest carbon-loss estimation in MHNP. The main objectives of the study includes the pattern of LUC in the MHNP during the period 1990, 2000, 2010 and 2017, their impacts on carbon dynamics and to analyze the major drivers of LUC in the MHNP.

\section{Materials and methods}

\section{Study area}

The study area is located at the foothills of the Himalaya Mountains around the

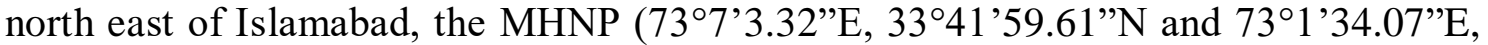
$\left.33^{\circ} 45^{\prime} 2.87^{\prime} \mathrm{N}\right)(\mathrm{WWF}, 2009)$ covers an estimated area of 17,386 hectares (ha) and composed of diverse ecological resources MHNP is dominated by Acacia modesta, Quercus incana, Pinus roxburghii, Dodonea viscosa, Olea ferruginea and ziziphus mauritiana and also have plant spp having medicinal value like Lantana camara (Asma et al., 2009). This park has about 1700 flowering species, more than 50 species of grasses 53 species of ferns and it is also rich in wildlife having common leopard, jackal, rhesus monkey, barking deer, porcupine, foxes and wild boars (WWF, 2009). The MHNP with the altitude of 469-1560 m, as shown in Figure 1, is made up of rugged slopes and gullies and the soil are characteristically composed of limestone (Butt et al., 2015). Temperature ranges between $-3.9{ }^{\circ} \mathrm{C}$ in January to $41.6{ }^{\circ} \mathrm{C}$ in June and average annual rainfall ranges between 245 and $1142 \mathrm{~mm}$ (PMD, 2015).

\section{Data acquisition}

Satellite images (LANDSAT) were obtained from United States geological survey (USGS) (http:// glovis.usgs.gov), for March 1990, 2000, 2010 and 2017. The images were selected based on quality and minimum cloud cover, see Table 1. In addition to using satellite images, ancillary data were collected which included topographic maps, aerial photographs, and ground truth data. In March 2017 using GPS, ground truth data in the form of reference points were collected which was used for image analysis and accuracy assessment. 


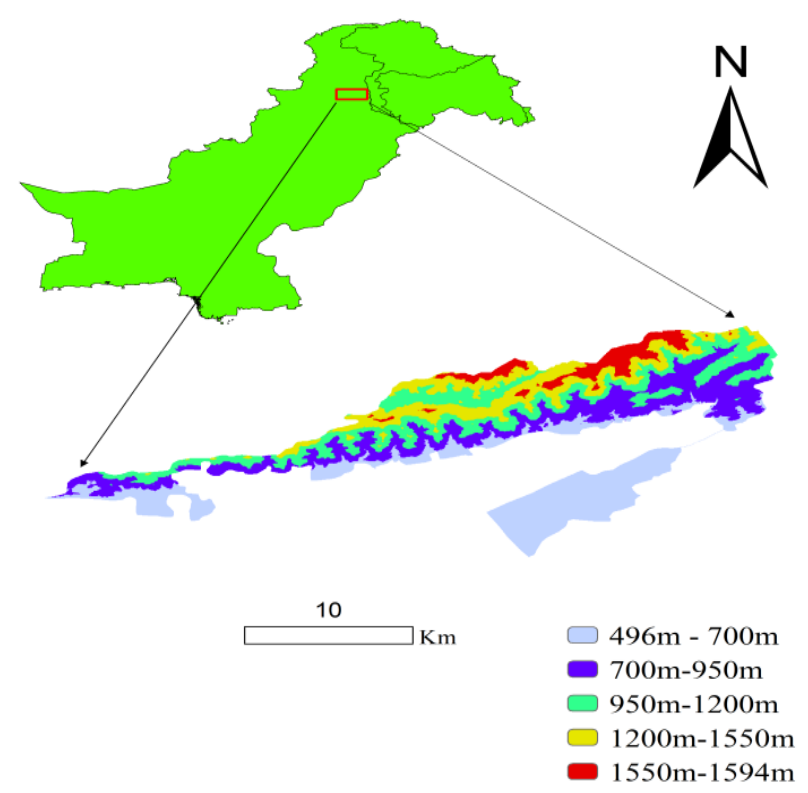

Figure 1. Map of Pakistan and elevation map of Margallah Hills National Park (MHNP)

Table 1. Satellite sensors specification

\begin{tabular}{c|c|c|c|c}
\hline Sensor & Year & Band/color & Resolution & Source \\
\hline Landsat 8 OIL imagery & 2017 & Multispectral & $30 \mathrm{~m}$ & USGS, glovis \\
Landsat 5 TM imagery & 2010 & Multispectral & $30 \mathrm{~m}$ & USGS, glovis \\
Landsat 7 ETM imagery & 2000 & Multispectral & $30 \mathrm{~m}$ & USGS, glovis \\
Landsat 5 TM imagery & 1990 & Multispectral & $30 \mathrm{~m}$ & USGS, glovis \\
\hline
\end{tabular}

\section{Preprocessing of satellite imagery}

Image pre-processing was preceded by the acquisition of topographic maps at the scale of $(1: 50,000)$ for the study area, obtained from a survey of Pakistan. The map was first scanned and exported into the processing software ArcGIS 10.2 and ENVI 5.1. Image pre-processing was necessary before the classification and change detection, for establishing a relationship between acquired data and biophysical processes (Abd ElKawy et al., 2011). To correct the geometric distortion of the satellite image geometric correction was performed from the topographic sheet as well as from the GPS by selecting 20 Ground Control Points (GCP's) around the study area. Then the geometrically corrected image was used to clip the region of interest (ROI). After that, the image was classified into five different classes such as dense forest (DF), open forest (OF), agricultural land (AL), settlements (SM), and water bodies (WB) with corresponding classes by assigning per-pixel signatures. On the bases of different digital number (DN), different colours were assigned to each landscape to differentiate them. Later on, Atmospheric, radiometric and topographic corrections were performed using ArcGIS 10.2 and ENVI 5.1. Training samples for each predetermined class were selected by delimiting polygons and spectral signatures for each land cover type derived from satellite imagery. Supervised classification was performed by using a maximum likelihood algorithm. To improve the quality of classification and to classify the unclassed pixels, post classification smoothing was performed. 


\section{Accuracy assessment}

The accuracy of the classified maps was crosschecked by 200 random GCPs. GCPs were randomly selected after which the user and producer accuracy were calculated for each LUC. Finally, the Kappa statistics were calculated by the observed and expected using Equation 1 (Chandra and Ghosh, 2006).

$$
\mathrm{k}=\frac{\text { Observed-Expected }}{1-\text { Expected }}
$$

Kappa statistics for 1990, 2000, 2010, and 2017 were 0.90, 0.91, 0.87, and 0.91 respectively.

\section{Land-use change detection map}

Post-classification change detection technique was performed by using ENVI 5.1. LUC detection map was developed by using the classified map of 1990 and 2017; the map of 1990 was used as the base map (Fig. 5). In an urban environment, the post classification has been used by various researchers effectively due to its efficiency in location, nature, and rate of change detection (Hardin et al., 2007). The annual rate of change in each land use type was measured according to Puyravaud (2003; Eq. 2):

$$
\mathrm{r}=\left\{\frac{1}{\left(\mathrm{t}_{\mathrm{z}}-\mathrm{t}_{1}\right)}\right\} \mathrm{x} \ln \left(\frac{\mathrm{A}_{2}}{\mathrm{~A}_{1}}\right)
$$

where, $A_{1}$ and $A_{2}$ are the areas of land use type at different time $t_{1}$ and $t_{2}$

\section{Carbon inventory}

Biomass carbon was assessed by field inventory in dense forest (DF) and open forest (OF). A total 150 sample plots of $20 \times 30 \mathrm{~m}$ were taken randomly in the study area $(75$ plots in DF and 75 in OF). In each sample plot, the diameter of all trees greater than $4 \mathrm{~cm}$ was measured at breast height $(\mathrm{DBH})$. The height of 20 trees per species was recorded, sufficient to construct $\mathrm{DBH} /$ height function of a specific plot. Abney's level was used to measure the height of the trees. The volume of all trees present in the sampling sites was measured using Equation 3 (Newbery, 2009), and total biomass $\mathrm{kg} \cdot \mathrm{ha}^{-1}$ was calculated by multiplying biomass with the wood density $\mathrm{kg} \mathrm{m}^{-3}$ of particular species using IPCC (2006) proposed guidelines.

$$
\text { Volume of tree }\left(\mathrm{m}^{3}\right)=\left(\frac{\pi}{4}\right) \times \mathrm{d}^{2} \times \mathrm{h} \times \mathrm{f}
$$

where $d^{2}$ is the square of $\mathrm{DBH}, h$ is height and $f$ is the form factor. Biomass of tree was calculated by using stem volume $\left(\mathrm{m}^{3}\right)$ and multiplying it by the wood density $\mathrm{kg} \mathrm{m}^{-3}$. The wood density values were confirmed by previous research and reports. Biomass expansion factor (BEF) for subtropical forests of Pakistan was used to determine the biomass of entire forests (Eq. 4; Haripriya, 2002; IPCC, 2006).

$$
\text { Biomass }(\mathrm{kg})=\text { Volume }\left(\mathrm{m}^{3}\right) \times \text { Wood density }\left(\mathrm{kg}^{\circ} \mathrm{m}^{-3}\right)
$$


For determining the biomass, carbon values of understory vegetation (USV) sub-plot of $4 \times 4 \mathrm{~m}$ was established in each sample plot. First, the vegetation in each plot was harvested, their fresh weight was recorded, and all the harvested materials were put into the labeled bags for further analysis. Then, the samples were dried in an oven at $72{ }^{\circ} \mathrm{C}$ for $48 \mathrm{~h}$ and their dried weights were measured for biomass. Similarly, litter, dead wood and cones present in the sub-plot were also collected, and followed the procedure mentioned above for USV for biomass carbon assessment. The soil samples were collected from the selected plots at the depth of $0-15 \mathrm{~cm}$ and $15-30 \mathrm{~cm}$ with the help of soil auger and core sampler in three replications. Each soil sample was weighed and labelled in the field. Core sampler of $0.0001256 \mathrm{~m}^{3}$ (diameter $=4 \mathrm{~cm}$, height $=10 \mathrm{~cm}$ ) was used to measure the bulk density of each soil sample. The soil samples were brought to the laboratory for further analysis. To measure the soil organic content the method of soil oxidizable organic carbon given by Walkley (1934) and Rayment (1992) was used. Carbon was determined by using total plant biomass convertible factor that is the representative of average biomass content of the plant. According to this convertible factor, the carbon content is $50 \%$ of the total plant biomass, this factor is used worldwide (Brown and Lugo, 1982; Saugier et al., 2001). The carbon values in the soil were $\left(\mathrm{MgC} \mathrm{ha}^{-1}\right)$ measured by multiplying the bulk density, carbon concentration and the thickness of the layer (Ahmad and Nizami, 2015).

\section{Carbon loss assessment}

The deforestation resulted in the conversion of forestland into AL and SM. Similarly it also resulted in the conversion of DF to OF. We assess the net loss of carbon value associated with deforestation. Change in carbon is determined by Equation 5 (Zheng et al., 2011)

$$
\Delta \mathrm{C}=\mathrm{TFC}_{\mathrm{t} 2}-\mathrm{TFC}_{\mathrm{t} 1}
$$

The annual rate of carbon loss is determined by Equation 6:

$$
\Delta \mathrm{C}=\frac{\left(\mathrm{TFC}_{\mathrm{tz}}-\mathrm{TFC}_{\mathrm{t} 1}\right)}{\left(\mathrm{t}_{\mathrm{z}}-\mathrm{t}_{1}\right)}
$$

$\Delta \mathrm{C}=$ Carbon loss or gain

$\mathrm{TFC}_{\mathrm{t} 2}=$ Total forest carbon at time $\mathrm{t} 2$

$\mathrm{TFC}_{\mathrm{t} 1}=$ Total forest carbon at time $\mathrm{t} 1$

\section{Results}

\section{Land uses and Land use change}

Our image analysis results showed that in 1990 the major land uses in the study area were a dense forest (DF), open forest (OF), agricultural land (AL), settlements (SM), and water bodies (WB). The land-use change statistics (Table 2) showed that from 1990 to 2017, the area under DF and WB were decreased, while we saw increase in the area under OF, AL, and SM as shown in Figures 2, 3, 4 and 5, respectively. In 1990, the area under DF was $55.87 \%$ and it was reduced to $49.55 \%$ in 2017 . The conversion of DF to other land uses resulted in a $6.32 \%$ decrease in the area under DF. Our results of LUC 
pattern analysis for three different periods (1990-2000, 2000-2010 and 2010 to 2017) are presented in Table 3.

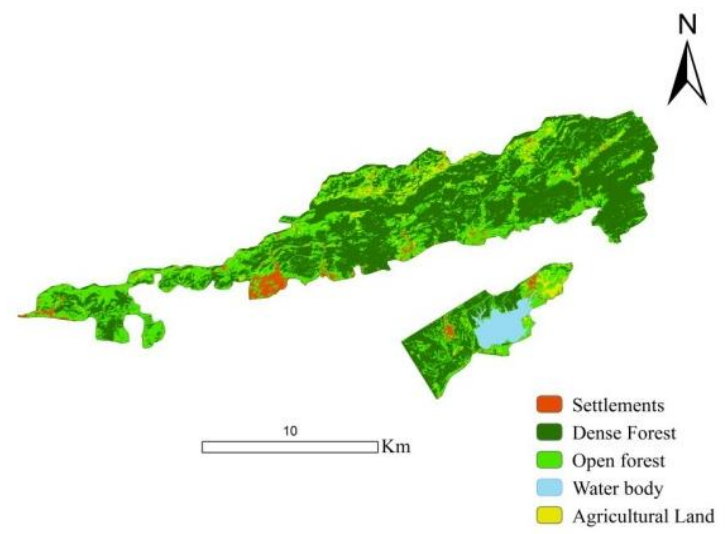

Figure 2. Land use cover map of Margallah Hills National Park (MHNP) for the year 1990

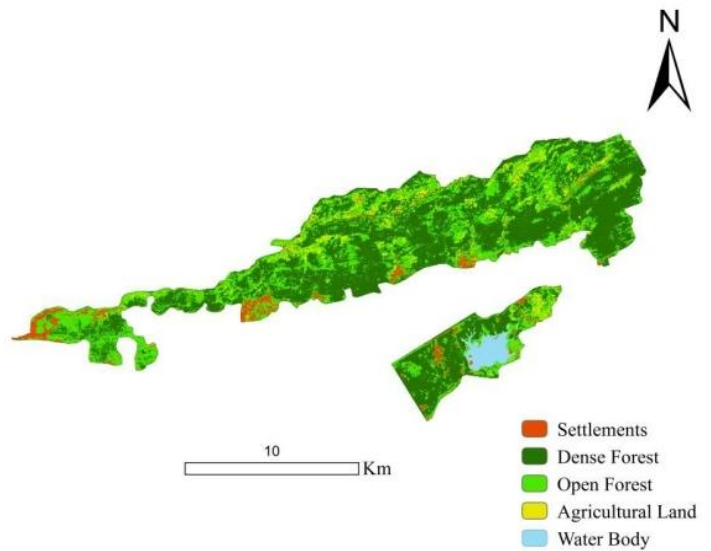

Figure 3. Land use cover map of Margallah Hills National Park (MHNP) for the year 2000



Figure 4. Land use cover map of Margallah Hills National Park (MHNP) for the year2010 


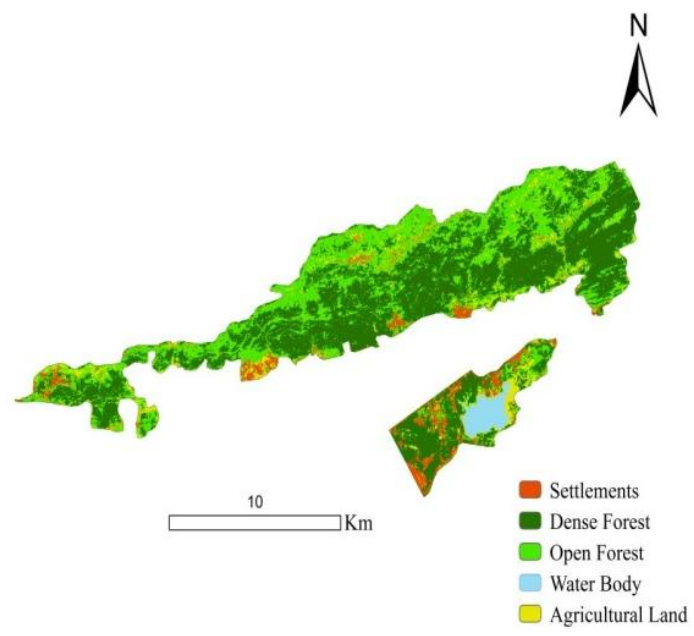

Figure 5. Land use cover map of Margallah Hills National Park (MHNP) for the year 2017

Table 2. Major land uses and LUC

\begin{tabular}{c|c|c|c|c|c|c|c|c}
\hline \multirow{2}{*}{$\begin{array}{c}\text { Land } \\
\text { uses }\end{array}$} & \multicolumn{2}{|c|}{ 1990 } & \multicolumn{2}{c|}{ 2000 } & \multicolumn{2}{c|}{ 2010 } & \multicolumn{2}{c}{ 2017 } \\
\cline { 2 - 9 } & Area (ha) & \% Area & Area (ha) & \% Area & Area (ha) & \% Area & Area (ha) & \% Area \\
\hline DF & 9697.1 & 55.87 & 9256 & 53.23 & 8989.2 & 51.7 & 8616.6 & 49.55 \\
OF & 5712.3 & 32.8 & 5892.7 & 33.52 & 5907.9 & 34.33 & 5957 & 34.26 \\
AL & 770.9 & 4.43 & 841.9 & 4.83 & 1020.6 & 5.86 & 1180.8 & 6.78 \\
SM & 662.5 & 3.8 & 760.5 & 4.37 & 940.3 & 5.4 & 1111.6 & 6.39 \\
WB & 544.2 & 3.1 & 534.9 & 3.07 & 528 & 3.03 & 520 & 2.99 \\
Total & 17387 & 99.97 & 100 & 17286 & 99.02 & 17386 & 100.32 & 17386 \\
\hline
\end{tabular}

Table 3. Periodic/annual pattern and trend of land uses and LUC

\begin{tabular}{|c|c|c|c|c|c|c|}
\hline $\begin{array}{l}\text { Land use } \\
\text { categories }\end{array}$ & $\begin{array}{c}1990-2000 \\
\text { change }(\%)\end{array}$ & $\begin{array}{c}\text { Annual } \\
\text { change (\%) }\end{array}$ & $\begin{array}{c}2000-2010 \\
\text { change }(\%)\end{array}$ & $\begin{array}{c}\text { Annual } \\
\text { change (\%) }\end{array}$ & $\begin{array}{c}2010-2017 \\
\text { change }(\%)\end{array}$ & $\begin{array}{c}\text { Annual } \\
\text { change }(\%)\end{array}$ \\
\hline Dense vegetation & -4.54 & -0.453 & -2.88 & -0.288 & -4.14 & -0.591 \\
\hline Open forest & +3.15 & +0.315 & +0.257 & +0.025 & +0.831 & +0.118 \\
\hline Agricultural land & +9.21 & +0.92 & +21.22 & +2.12 & +15.69 & +2.22 \\
\hline Settlements & +14.79 & +1.47 & +23.64 & +2.36 & +18.21 & +2.2 \\
\hline Water body & -1.7 & -0.17 & -1.2 & -0.12 & -1.5 & -0.12 \\
\hline
\end{tabular}

The results showed that during the period 1990-2000, DF decrease by $4.54 \%$ $\left(0.453 \% \mathrm{yr}^{-1}\right)$, during $2000-2010$, DF reduced by $2.88\left(0.288 \% \mathrm{yr}^{-1},\right)$ and $4.14 \%$ $\left(0.591 \% \mathrm{yr}^{-1}\right)$, respectively as shown in Table 3. Apart from a decrease in area under DF, major changes were also observed for WB, OF, AL and SM (Table 4 and Fig. 6). Our results showed that a total of 1268.78 ha forest land (DF, OF) has been converted into other land uses from 1990 to 2017 and Indicating the increasing scale of anthropogenic pressure on forest resources of the Park as shown in Figure 7. 
Table 4. LUC statistics from 1990 to 2017

\begin{tabular}{|c|c|c|c|}
\hline Land use type & $\begin{array}{l}\text { Land use change to } \\
\text { other land use }\end{array}$ & $\begin{array}{l}\text { Area change (ha) } \\
(1990-2017)\end{array}$ & Total area change (ha) \\
\hline \multirow{3}{*}{ Agricultural land } & Open forest & 345.4200 & \multirow{3}{*}{335.69} \\
\hline & Dense forest & 47.9700 & \\
\hline & Settlement & 42.3000 & \\
\hline \multirow{3}{*}{ Dense vegetation } & Agricultural land & 40.1 & \multirow{3}{*}{2242.94} \\
\hline & Open forest & $1,944.9000$ & \\
\hline & Settlement & 257.9400 & \\
\hline \multirow{3}{*}{ Open forest } & Agricultural & 528.0300 & \multirow{3}{*}{2291.22} \\
\hline & Settlements & 442.7100 & \\
\hline & Dense forest & $1,320.4800$ & \\
\hline \multirow{3}{*}{ Settlements } & Agricultural land & 69.3000 & \multirow{3}{*}{276.84} \\
\hline & Open forest & 180.0000 & \\
\hline & Dense forest & 27.5400 & \\
\hline \multirow{4}{*}{ Water body } & Dense forest & 2.3400 & \multirow{4}{*}{136.35} \\
\hline & Open forest & 14.4000 & \\
\hline & Settlements & 1.5300 & \\
\hline & Agricultural land & 118.0800 & \\
\hline
\end{tabular}

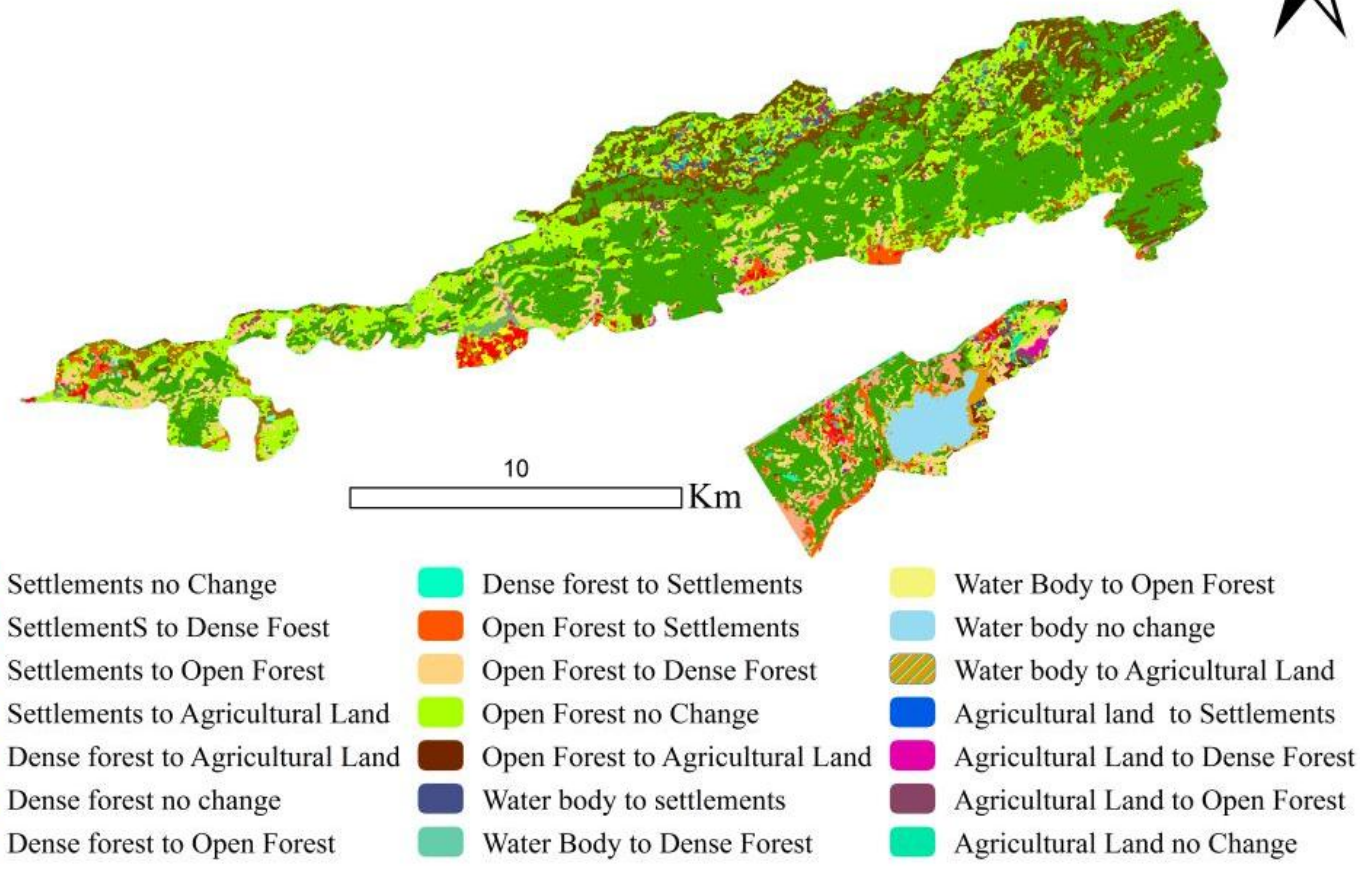

Figure 6. Statistical land classes change in Margallah Hills National Park (MHNP) from 1990 to 2017 


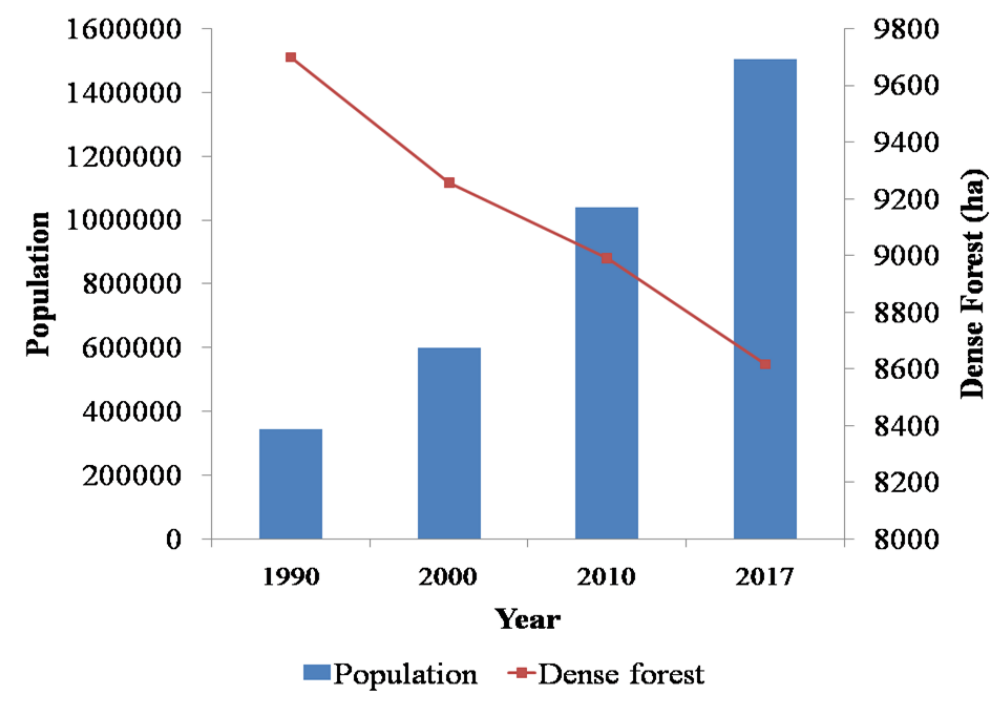

Figure 7. Increase in population of Islamabad city

\section{Carbon dynamics and carbon losses}

The estimated carbon value recorded in DF is $164.14 \pm 8.96 \mathrm{MgC} \mathrm{ha}^{-1}$, whereas it is in $94.62 \pm 8.75 \mathrm{MgC} \mathrm{ha}^{-1}$ in $\mathrm{OF}$ (Table 5). In each forest, the higher value of carbon is recorded for upper storey vegetation (UPSV) followed by soil, understorey vegetation and litter dead wood. The results of the total carbon stock (Table 6) showed that in 1990 the total forest carbon stock was $2131 \mathrm{GgC}$. Similarly, the total forest carbon stock was reduced in 2000, 2010 and 2017 i.e. $2076 \mathrm{GgC}, 2034 \mathrm{GgC}$, and $1987 \mathrm{GgC}$ respectively. These findings revealed the decreasing trend in carbon value associated with LUC. Taken together as a whole the present results indicated that LUC accounted for $154 \mathrm{GgC}$ loss from 1990 to 2017.

Table 5. Carbon pool comparison

\begin{tabular}{c|c|c}
\hline Carbon pool & Dense forest $\mathbf{( M g C \cdot h a ^ { - \mathbf { 1 } } )}$ & Open forest $\left.\mathbf{( M g C \cdot h a}^{\mathbf{- 1}}\right)$ \\
\hline Upper storey & $105.69 \pm 22.58$ & $40.78 \pm 24.55$ \\
Understorey & $2.3 \pm 0.27$ & $1.81 \pm 0.41$ \\
Litter/dead wood & $1.13 \pm 0.32$ & $0.96 \pm 0.22$ \\
Soil & $54.97 \pm 12.67$ & $51.06 \pm 9.81$ \\
Total carbon & $164.14 \pm 8.96$ & $94.62 \pm 8.75$ \\
\hline
\end{tabular}

Table 6. Total stored carbon

\begin{tabular}{c|c|c|c|c|c}
\hline & $\begin{array}{c}\text { Dense forest } \\
\text { (ha) }\end{array}$ & $\begin{array}{c}\text { Open forest } \\
\text { (ha) }\end{array}$ & $\begin{array}{c}\text { Carbon DF } \\
(\mathbf{G g C})\end{array}$ & Carbon OF $(\mathbf{G g C})$ & Total carbon $(\mathbf{G g C})$ \\
\hline 1990 & 9697.1 & 5712.3 & 1591 & 540 & 2131 \\
2000 & 9256 & 5892.7 & 1528 & 557 & 2076 \\
2010 & 8989.2 & 5907.9 & 1475 & 559 & 2034 \\
2017 & 8616.6 & 5957 & 1414 & 573 & 1987 \\
\hline
\end{tabular}




\section{Discussion}

\section{Land use and land cover change}

Natural forests are mostly located in the temperate and subtropical regions of Pakistan where LUC and deforestation are continuous processes. The increase in SM and AL from 1990-2017, indicate the scale of LUC in the park. We found that in the last 27 years SM has increased by $67.78 \%$ as compared to our base year 1990 . Between 1990 and 2017 SM for Islamabad increased from 16,281 to 51,039 ha as shown in Figure 8. This increase is attributed to the migration of people from villages to cities for better health facilities, education, and job opportunities. Also, settlement expansion (built-up areas) around Rawal Lake, have caused an increase in SM in and around the park (Hassan et al., 2016). Similarly, due to unsustainable agriculture practiced by local villagers, AL expanded from 770.9 ha in 1990 to 1180.8 ha in 2017.



Figure 8. Temporal change in classes

Increase in settlements from 10 villages in 1990 to over 20 villages in 2017 may have induced AL expansion in the MHNP due to population pressures (Khalid et al., 2015). Related studies also show settlements to have increased by $23 \%$ in the MHNP between 1992 and 2012 (Hassan et al., 2016). The periodic and annual rates of increase in the OF, AL, and SM were notably higher between 2010 and 2017. This may be due to an increase in population between 2010 and 2017 per $\mathrm{km}^{2}$ of Islamabad (PBS, 2017). This increase in population around the park causes major shifts in LUC. Overall, an average annual loss in DF for MHNP is $0.42 \%$ which is much higher than the $0.21 \%$ average annual deforestation from terrestrial protected areas of the Philippines (Apan et al., 2017).

For instance, the DF in the base year 1990 was 9697.1 ha and decreased to 8616.69 ha in 2017, as shown in normalized difference vegetation index (NDVI) map (Fig. 9). This decreasing trend in DF is similar to that reported by Malik and Husain (2003) which was 59.4\% in 1990 and decreased to 56.3\% in 1998. The conversion of DF into OF in and around the park could be attributed to unregulated and illegal logging 
by local villagers for fuelwood, livestock grazing, and forest fires. As elsewhere around the globe, forest fires are a regular part of MHNP especially during the drier months of summer (Chanthalath et al., 2017). These fires usually damage the DF more severely as compared to OF. The continuous reduction in the area under DF and increase in areas under OF, AL, and SM showed DF to have been mainly converted into OF, AL, and SM.


Figure 9. a. Normalized difference vegetation index (NDVI) for(a) 1990 and (b) 2017

\section{Carbon dynamics and carbon losses}

The calculated value of carbon varied between $94.62 \pm 8.75 \mathrm{MgCha}^{-1}$ in OF to $164.14 \pm 8.96 \mathrm{MgC} \mathrm{ha}^{-1}$ in DF with average carbon stored in forestland being $129 \pm$ $8.85 \mathrm{MgC} \mathrm{ha}{ }^{-1}$. Similar results were reported for carbon stock in Ghoragali, Pakistan (subtropical/chir pine) (Nizami, 2012). Similarly, our present estimates are also inconsistent with the reported value by Rana et al. (1989) from the Himalayan region of India.

The conversion of forestland to other land uses resulted in carbon loss from $2131 \mathrm{GgC}$ for 1990 to $1977 \mathrm{GgC}$ in 2017. Same results were previously reported which showed loss of $32.7 \mathrm{PgC}$ from the protected areas of Brazil Amazonia in 2014 (Nogueira et al., 2018). Similarly, in the protected areas of US from 1700-2005 more than 3 million $\mathrm{km}^{2}$ of forest land, grassland and shrub land were converted to agricultural land that caused 10,607 TgC loss (Lu et al., 2018). This reduction in carbon supports the fact that the transformation of forestland to other land uses reduces the carbon storage potential of forestland. Deforestation, agricultural and settlement expansion attributed to population growth, resulted in forest conversion, hence decrease in carbon stock. Over these different periods, the highest rate of carbon losses was 
recorded for the period 2010-2017 as shown in Table 7. This period also coincided with the maximum of population growth and human migration within the study area. According to the population statistics data (PBS, 2017) between 2010 and 2017, 0.422 million people migrated to Islamabad as compared to 0.245 million during 1990-2000. The expansion in AL and SM usually occurred near the old settlements, where local people grow crops. Although this LUC affects carbon loss, the intensity is much higher where DF is converted into SM, AL, or OF (Zheng et al., 2011). Within the past seven years (2010-2017) the rate of annual DF loss calculated was $-0.59 \%$ much higher than in the first and in the second decade. This is due to an increase in hiking trails, roads, and recreational spots in and around the park thus directly affecting natural forest cover and carbon storage.

Table 7. Carbon loss

\begin{tabular}{c|c|c|c|c}
\hline \multirow{2}{*}{} & \multicolumn{2}{|c|}{ Total carbon loss/gain (MgC) } & \multirow{2}{*}{$\begin{array}{c}\text { Net carbon loss } \\
\text { (MgC) }\end{array}$} & $\begin{array}{c}\text { Net annual carbon } \\
\text { loss }\left(\mathbf{M g C} \cdot \mathbf{y r}^{-1}\right)\end{array}$ \\
\cline { 2 - 3 } & $\mathbf{D F}$ & $\mathbf{O F}$ & -55315.57 & -5531.55 \\
$1990-2000$ & -72386.71 & +17071.13 & -42344.84 & -4234.48 \\
$2000-2010$ & -43783.21 & +1438.36 & -56499.22 & -8071.31 \\
\hline $2010-2017$ & -61145.52 & +4646.30 & \\
\hline
\end{tabular}

The population of Islamabad increased from 343,000 to over 1,502,000 from 1990 to 2017. These demographic factors in conjunction with other environmental and socioeconomic factors constitute major driving forces of LUC in and around MHNP (PBS, 2017). Additionally, in 1990 the population living in villages around Margallah Hills was estimated at about 20,000 but this increased to over 90,000 in 2017 distributed across 20 villages (Khalid et al., 2015). This demographic pressure is also a major threat to the sustainability of these natural ecosystems (Khan and Khan, 2009; Ali and Nyborg, 2010; Cochard and Dar, 2014). This demographic pressure also drives the expansion of built-up areas and agricultural land, as well as wood extraction (fuelwood, artisanal and commercial logging), which are drivers of forest cover change and degradation of natural ecosystems (Moffat et al., 1998; Agudelo-Vera et al., 2011). Other studies have also shown that anthropogenic activities are major threats to global forest cover (Rokityanskiy et al., 2007; Zomer et al., 2008; Ahmad and Nizami, 2015; Saeed et al., 2016). Historically, this increase in population and other underlying factors particularly in developing countries have been observed to be the most important driving force of LUC (Rosero-Bixby and Palloni, 1998). According to (Lambin et al., 2003), these underlying drivers of LUC are poverty, population growth, and socioeconomic situation. Increased population often results in the migration of people in search of farmlands and open forests are easier to convert to agricultural land (Meli and Meli, 2015). Rural communities around the MHNP have witnessed an unregulated and uncontrolled urban expansion which has pushed these communities into forested lands of the area. Stone quarrying for cement making is also a contributor to carbon loss because Margallah hills have a high quality of limestone, shale, and sandstone used for cement production (Muhammad et al., 2013). There are over 700 stone quarries around the MHNP with dire consequences for the surrounding vegetation, plant and animal species, namely 38 species of mammals and over 600 plant species in the MHNP (Dawn News, August 23, 2010). In a related study, Ali et al. (2006) observed wood harvesting 
for commercial and household consumption, forest disease, and unregulated harvesting to be main drivers of deforestation in the watershed area of the MHNP.

Forest fires regularly occur in the MHNP due to fallen dry needles of chir pine in summer and dry season around May. According to de Groot et al. (2009), about 40.9\% to $53.9 \%$ of carbon is lost annually due to forest fires depending on the intensity of forest fire. Most of the forest fires that occurred in subtropical forests of Pakistan are accidental due to recreational activities and negligence. Increasing trends of forest surface fires have been observed in subtropical forests of Pakistan (Nafees and Asghar, 2009). Forest fires are known to reduce soil carbon, soil erosion, reduction in understory vegetation and soil bareness (Jaiswal et al., 2002). The grazing and trampling of livestock severely affect vegetation regeneration thus also contributing towards LUC. Khalid et al. (2015) found that MHNP has to bear the pressure of 12,000 and 13,000 domestic livestock grazing.

\section{Conclusion}

The knowledge obtained from this study may serve as an input into the rehabilitation and management of degraded forest ecosystems in Pakistan and in the world. Furthermore, the MHNP is located in Islamabad and near Rawalpindi, which are Pakistan's most important twin cities with high demographic pressures. The present Study highlighted the temporal loss of forest carbon sink with the land use change in MHNP. The study also discussed the major drivers of land use change and carbon loss in MHNP i.e. stone crushing for cement making, fuel wood for commercial, population pressure, AL and SM expansion with detrimental effects on the ecosystem of the park. Moreover, the building of new infrastructures in the twin cities has resulted in a decrease in the forest area. These factors coupled with weak governmental policies, and inadequate land use management plans, facilitate a reduction in forest biomass and ultimately carbon sequestered in the MHNP. Deforestation control through improved forest management, appropriate forest conservation policies, development of land use management plans and urbanization regulations will help curtail, curb and reverse this deforestation process. This study provides results and recommendations to researchers for future studies focusing on especially the effects of land use change on wildlife habitat of MHNP and the effects of carbon loss on the local environment of MHNP. Additionally, an improvement in the national forest monitoring capacity and the implementation of REDD+ arrangement and sustainable land and forest management approaches can control the current forest cover loss, and carbon loss resulting from LUC.

Acknowledgements. This research was supported by the National Science Foundation of China (No.U1710123), the Natural Science Foundation of Beijing (Key Program, No.6161001), and "Precision Forestry Key Technology and Equipment Research" of medium long term project of Beijing Forestry University (No. 2015ZCQ-LX-01).

\section{REFERENCES}

[1] Abatzoglou, J. T., Kolden, C. A., Williams, A. P., Lutz, J. A., Smith, A. M. S. (2017): Climatic influences on interannual variability in regional burn severity across western US forests. - International Journal of Wildland Fire 26: 269-275. 
[2] Abd El-Kawya, O. R., Rod, J. K., Ismail, H. A., Suliman, A. S. (2011): Land use and land cover change detection in the western Nile delta of Egypt using remote sensing data. Applied Geography 31: 483-494.

[3] Agudelo-Vera, C. M., Mels, A. R., Keesman, K. J., Rijnaarts, H. H. M. (2011): Resource management as a key factor for sustainable urban planning. - Journal of Environmental Management 92: 2295-2302.

[4] Ahmad, A., Nizami, S. M. (2015): Carbon stocks of different land uses in the Kumrat valley, Hindu Kush Region of Pakistan. - Journal of Forest Research 26: 57-64.

[5] Ahmad, A., Nizami, S. M., Marwat, K. B., Muhammad, J. (2015): Annual accumulation of carbon in the coniferous forest of Dir Kohistan: An inventory based estimate. Pakistan Journal of Botany 47: 115-118.

[6] Ali, J., Nyborg, I. L. P. (2010): Corruption or an alternative system? Re-assessing corruption and the role of the forest services in the northern areas, Pakistan. International Forestry Review 12: 209-220.

[7] Ali, T., Shahbaz, B., Sulehri, A. (2006): Analysis of myths and realities of deforestation in northwest Pakistan: implications for forestry extension. - International Journal of Agriculture and Biology 8: 107-110.

[8] Apan, A., Suarez, L. A., Maraseni, T., Castillo, J. A. (2017): The rate, extent and spatial predictors of forest loss (2000-2012) in the terrestrial protected areas of the Philippines. Applied Geography 81: 32-42.

[9] Asma, J., Mir, A. K., Mushtaq, A., Muhammad, Z., Farooq, A. (2009): Indigenous uses of economically important flora of Margallah Hills National Park, Islamabad, Pakistan. African Journal of Biotechnology 8: 763-784.

[10] Bowman, D. M. J. S., Williamson, G. J., Abatzoglou, J. T., Kolden, C. A., Cochrane, M. A., Smith, A. M. S. (2017): Human exposure and sensitivity to globally extreme wildfire events. - Nature Ecology and Evolution 1: 58.

[11] Butt, A., Shabbir, R., Ahmad, S. S., Aziz, N., Nawaz, M., Shah, M. T. A. (2015): Land cover classification and change detection analysis of Rawal watershed using remote sensing data. - Journal of Biodiversity and Environmental Sciences 6: 236-248.

[12] Chandra, A., Ghosh, S. K. (2006): Remote Sensing and Geographical Information System. - Alpha Science Int'l Ltd, Oxford, U.K.

[13] Chanthalath, X., Yong, L., Beckline, M., Inthilath, S. (2017): Assessing the socioecological perspectives of eucalyptus cultivation and plantation expansion in Laos. Open Access Library Journal 4: 1-15.

[14] Cochard, R., Dar, M. E. U. I. (2014): Mountain farmer's livelihoods and perceptions of forest resource degradation at Machiara National Park, Pakistan-administered Kashmir. Environmental Development 10: 84-103.

[15] Dawn News (2010): Quarrying at Margallas Pak-EPA, ICT pass on the buck. - 23 August 2010.

[16] de Groot, W. J., Pritchard, J. M., Lynham, T. J. (2009): Forest floor fuel consumption and carbon emissions in Canadian boreal forest fires. - Canadian Journal of Forest Research 39: 367-382.

[17] FAO (2015): Global Forest Resourse Assesment. - FAO, Rome.

[18] Gao, J., Liu, Y. (2010): Determination of land degradation causes in Tongyu County, Northeast China via land cover change detection. - International Journal of Applied Earth Observation and Geo-Information 12: 9-16.

[19] Hardin, P. J., Jackson, M. W., Otterstrom, S. M. (2007): Mapping, Measuring, and Modeling Urban Growth. - In: Jensen, R. R., Gatrell, J. G., McLean, D. (eds.) GeoSpatial Technologies in Urban Environments: Policy, Practice and Pixels. Springer, Heidelberg.

[20] Haripriya, G. S. (2002): Biomass carbon of truncated diameter classes in Indian forests. Forest Ecology and Management 168: 1-13. 
[21] Harris, P. M., Ventura, S. J. (1995): The integration of geographic data with remotely sensed imagery to improve classification in an urban area. - Photogrammetric Engineering and Remote Sensing 61: 993-998.

[22] Hassan, Z., Shabbir, R., Ahmad, S. S., Malik, A. H., Aziz, N., Butt, A., Erum, S. (2016): Dynamics of land use and land cover change (LULCC) using geospatial techniques: a case study of Islamabad Pakistan. - SpringerPlus 5: 812-822.

[23] Houghton, R. A. (2003): Revised estimates of the annual net flux of carbon to the atmosphere from changes in land use and land management. - Tellus B 55: 378-390.

[24] IPCC (2006). Inter-Governmental Panel on Climate Change (IPCC) Guidelines for National Greenhouse Gas Inventories. - IPCC, Geneva.

[25] Jaiswal, R. K., Mukherjee, S., Raju, K. D., Saxena, R. (2002): Forest fire risk zone mapping from satellite imagery and GIS. - International Journal of Applied Earth Observation and Geoinformation 4: 1-10.

[26] Kennedy, R. E., Townsend, P. A., Gross, J. E., Cohen, W. B., Bolstad, P., Wang, Y. Q., Adams, P. (2009): Remote sensing change detection tools for natural resource managers: Understanding concepts and tradeoffs in the design of landscape monitoring projects. Remote Sensing and Environment 113: 1382-1396.

[27] Khalid, N., Ahmad, S., Erum, S., Butt, A. (2015): Monitoring forest cover change of Margalla Hills over a period of two decades (1992-2011): A spatiotemporal perspective. Journal of Ecosystem and Ecography 6: 174-181.

[28] Khan, A., Ahmad, A., Rahman, Z., Qureshi, R., Muhammad, J. (2015): The assessment of carbon stocks in the oak scrub forest of Sheringal Valley Dir Kohistan. - Open Journal of Forestry 5: 510-517.

[29] Khan, S. R., Khan, S. R. (2009): Assessing poverty-deforestation links: Evidence from Swat, Pakistan. - Ecological Economics 68: 2607-2618.

[30] Lambin, E. F. (1997): Modeling and monitoring land cover change processes in tropical regions. - Progress in Physical Geography 21: 375-393.

[31] Lambin, E. F., Geist, H. J., Lepers, E. (2003): Dynamics of land-use and land-cover change in tropical regions. - Annual Review of Environment and Resources 28: 205-241.

[32] Lu, D., Mausel, P., Brondizio, E., Moran, E. (2004): Change detection techniques. International Journal of Remote Sensing 25: 2365-2401.

[33] Lu, X., Zhou, Y., Liu, Y., Le, Page, Y. (2018): The role of protected areas in land use/land cover change and the carbon cycle in the conterminous United States. - Global Change Biology 24: 617-630.

[34] Malik, R. N., Husain, S. Z. (2003): Evaluating Deforestation Using Landsat TM and SPOT XS Data in Dry Sub-tropical Forest of Margalla Hills, Northwest of Pakistan. - In: Benes, T. (ed.) Geoinformation for European-Wide Integration, pp. 429-434. Millpress, Rotterdam.

[35] Martin, H., Tracy, J. (2007): Linking requirements with capabilities for deforestation monitoring in the context of the UNFCCC-REDD process. - Environmental Research Letters 2: 045025.

[36] Meli, F., Meli, V. (2015): Modelling drivers of forest cover change in the Santchou wildlife reserve, west Cameroon using remote sensing and land use dynamic degree indexes. - Canadian Journal of Tropical Geography 2: 29-42.

[37] Moffat, D., Ngoile, M. A. K., Linden, O., Francis, J. (1998): The reality of the stomach: coastal management at the local level in eastern Africa. - AMBIO 27: 590-598.

[38] Muhammad, A., Muhammad, K. S., Elsamoal, E. A., Amna, H., Bin, Z., Cao, Y. (2017): Biomass and carbon stocks estimation in Chichawatni irrigated plantation in Pakistan. International Journal of Agriculture \& Biology 19: 1339-1349.

[39] Muhammad, F. I., Mobushir, R. K., Amir, H. M. (2013): Land use change detection in the limestone exploitation area of Margalla Hills National Park (MHNP), Islamabad, Pakistan using geo-spatial techniques. - Journal of Himalayan Earth Sciences 46: 89-98. 
[40] Mukete, B., Sun, Y., Baninla, Y., Achem, B., Bakia, M., Sajjad, S., Tamungang, R., Jaba, W., Chalwe, P. (2017): Perspectives of remote sensing and GIS applications in tropical forest management. - American Journal of Agriculture and Forestry 5: 33-39.

[41] Nabuurs, G. J., Linder, M., Verkerk, P. J., Gunia, K., Deda, P., Michalak, R., Grassi, G. (2013): First signs of carbon sink saturation in European forest biomass. - Nature Climate Change 3: 792-796.

[42] Nafees, M., Asghar, A. (2009): Forest fire events in Swat Valley, Pakistan. - Pakistan Journal of Plant Science 15: 31-37.

[43] Nogueira, E. M., Yanai, A. M., de Vasconcelos, S. S., de Alencastro Graça, P. M. L., Fearnside, P. M. (2018): Carbon stocks and losses to deforestation in protected areas in Brazilian Amazonia. - Regional Environmental Change 18: 261-270.

[44] Newbery, D. M., Philip, M. S. (2009): Measuring trees and forests. - Journal of Tropical Ecology 11: 204-204.

[45] Nizami, S. M. (2012): The inventory of the carbon stocks in sub tropical forests of Pakistan for reporting under Kyoto Protocol. - Journal of Forestry Research 23: 377-384.

[46] Pan, Y., Birdsey, R. A., Fang, J., Houghton, R., Kauppi, P. E., Kurz, W. A., Phillips, O. L., Shvidenko, A., Lewis, S. L., Canadell, J. G. et al. (2011): A large and persistent carbon sink in the world's forests. - Science 333: 988-993.

[47] PBS (2017): Provisional Summary Results of 6th Population and Housing Census-2017. - Pakistan Bureay of Statistics, Islamabad, Pakistan.

[48] PMD (2015): Rainfall statistics of Islamanad. - Pakistan Metrological Department, Islamsbad, Pakistan.

[49] Puyravaud, J. P. (2003): Standardizing the calculation of the annual rate of deforestation. - Forest Ecological Management 177: 593-596.

[50] Radeloff, V. C., Nelson, E., Plantinga, A. J., Lewis, D. J., Helmers, D., Lawler, J. J., Withey, J. C., Beaudry, F., Martinuzzi, S., Butsic, V. et al. (2012): Economic-based projections of future land use in the conterminous United States under alternative policy scenarios. - Ecological Applications 22: 1036-1049.

[51] Rana, B. S., Singh, S. P., Singh, R. P. (1989): Biomass and net primary productivity in Central Himalayan forests along an altitudinal gradient. - Forest Ecology and Management 27: 199-218.

[52] Rayment, G. E., Higginson, F. R. (1992): Australian Laboratory Handbook of Soil and Water Chemical Methods. - Inkata Press, Port Melbourne.

[53] Rembold, F., Carnicelli, S., Nori, M., Ferrari, A. (2000): Use of aerial photographs, Landsat TM imagery and multidisciplinary field survey for land-cover change analysis in the lakes region (Ethiopia). - International Journal of Applied Earth Observations and Geo-Information 2: 181-189.

[54] Rokityanskiy, D., Benítez, P. C., Kraxner, F., McCallum, I., Obersteiner, M., Rametsteiner, E., Yamagata, Y. (2007): Geographically explicit global modeling of landuse change, carbon sequestration, and biomass supply. - Technology Forecasting and Social Change 74: 1057-1082.

[55] Rosero-Bixby, L., Palloni, A. (1998): Population and deforestation in Costa Rica. Population and Environment 20: 149-185.

[56] Saeed, S., Ashraf, M. I., Ahmad, A., Rahman, Z. (2016): The Bela forest ecosystem of District Jhelum, a potential carbon sink. - Pakistan Journal of Botany 48: 121-129.

[57] Saugier, B., Roy, J., Mooney, H. A. (2001): Principles of Terrestial Ecosystem Ecology. - Academic Press, San Diego.

[58] Searchinger, T., Heimlich, R., Houghton, R. A., Dong, F., Elobeid, A., Fabiosa, J., Tokgoz, S., Hayes, D., Yu, T. H. (2008): Use of U.S. croplands for biofuels increases greenhouse gases through emissions from land-use change. - Science 319: 1238-1240.

[59] Sudhakar Reddy, C., Ram, R. K., Pattanaik, C., Joshi, P. K. (2008): Assessment of largescale deforestation of Nawarangpur district, Orissa, India: a remote sensing based study. - Environmental Monitoring and Assessment 154: 325-331. 
[60] Thompson, J. R., Foster, D. R., Scheller, R., Kittredge, D. (2011): The influence of land use and climate change on forest biomass and composition in Massachusetts, USA. Ecological Applications 21: 2425-2444.

[61] Ullah, S., Farooq, M., Shafique, M., Siyab, M. A., Kareem, F., Dees, M. (2016): Spatial assessment of forest cover and land-use changes in the Hindu-Kush mountain ranges of northern Pakistan. - Journal of Mountain Science 13: 1229-1237.

[62] Walkley, A., Black, I. A. (1934): An examination of Degtjareff methods for determining soil organic matter and proposed modification of the chromic acid titration method. - Soil Science 37(1): 29-38.

[63] Weng, Q. (2001): A remote sensing-GIS evaluation of urban expansion and its impacts on temperature in the Zhujang Delta, China. - International Journal of Remote Sensing 22: 1999-2014.

[64] WWF (2009): Boundary Deliniation of Margallah Hills National Park (Pakistan). WWF, Pakistan.

[65] Yuan, D., Elvidge, C. D., Lunetta, R. S. (1999): Survey of Multi-Spectral Methods for Land Cover Change Analysis. - In: Lunetta, R. S., Elvidge, C. D. (eds.) Remote Sensing Change Detection: Environmental Monitoring Methods and Applications. Francis, London.

[66] Zhao, G. X., Lin, G., Warner, T. (2004): Using Thematic Mapper data for change detection and sustainable use of cultivated land: a case study in the Yellow River delta, China. - International Journal of Remote Sensing 25: 2509-2522.

[67] Zheng, D., Heath, L. S., Ducey, M. J., Smith, J. E. (2011): Effects of land use/cover change and harvests on forest carbon dynamics in northern states of the United States from remote sensing and inventory data: 1992-2001. - Forest Science 57: 525-534.

[68] Zomer, R. J., Trabucco, A., Bossio, D. A., Verchot, L. V. (2008): Climate change mitigation: A spatial analysis of global land suitability for clean development mechanism afforestation and reforestation. - Agricultural Ecosystem and Environment 126: 67-80. 